\title{
Putting the crisis to work: The real estate sector and London's housing crisis
}

\author{
Frances Brill *, Mike Raco \\ Bartlett School of Planning, UCL, 14 Upper Woburn Place, London, UK
}

\section{A R T I C L E I N F O}

\section{Keywords:}

London

Urban politics

Housing crisis

Investors

\begin{abstract}
A B S T R A C T
The idea of 'crisis' plays an important role in academic and policy imaginations (Heslop and Ormerod, 2020), particularly since the global financial crisis. Across major western cities, at the same time as policy-makers have had to respond to 'the (economic) crisis', many have also experienced intense 'housing crises' and the acute divergence of average incomes and house prices. In response, cities such as London have become central sites in debates around housing acquisition by the ultra-wealthy, land value extraction and growing levels of unaffordability. However, much critical geography research on housing crises is state-centred or focused on civil society impacts, with relatively little reflection on the real estate sector and the work that crisis does as a narrative in shaping institutionalised and actor-centred practices. In this paper, we draw on in-depth research with developers, investors, and advisors in London to argue that crisis-driven policy responses have created political risk which is differentially experienced by actors across the sector, with large housebuilders and advisors benefitting whilst smaller niche developers move out. Moreover, we show how consultants, investors and developers have used the crisis situation to create new geographies, products and investor types in the housing market. These, in turn, require regulatory support and demonstrate the inherently political nature of crisis narratives' use. We use the London case to broaden understandings of the impact that conceptualisations of 'crisis' have on urban and regional planning practices, and how these influence and shape processes of contemporary urban development.
\end{abstract}

\section{Introduction}

The idea of 'crisis' has played an important role in contemporary academic and policy imaginations (Roitman, 2013). In particular, in light of the 2008 Global Financial Crisis [GFC], there have been extensive debates around financial crises and their consequences. Cities have experienced the GFC and (the often related) global 'housing crisis' simultaneously, exacerbated by housing becoming a globally attractive investment class, valued at an estimated \$174 trillion (Williams, 2020). Acute development pressures have meant that cities such as New York, London and Paris have witnessed house prices more than tripling in the last 20 years, reducing affordability (Le Galès and Pierson, 2018). In response, the housing sector has been subject to persistent policy changes at different scales. However, many of these have failed to tackle structural inequalities, and have only succeeded in expanding housing for the relatively well-off middle classes and luxury market, as well as focusing on smaller households, short-term visitors, or students.

The focus of much writing, especially from a political econ omy perspective, has elided crisis responses with the pursuit of more market-oriented and delivery-focused state reforms
(Edwards, 2016; Madden \& Marcuse, 2016). It demonstrates that when regulators grapple with housing market failures, the tendency has been to focus on selective forms of de-regulation to support real estate firms to generate new levels of supply. Well-documented efforts have been made, in multiple contexts, to attract investors and to liberalise planning systems, with significant negative impacts on citizen welfare (Beswick et al., 2016). Narratives of crisis are used to legitimise such reforms (Brill \& Durrant, 2021; Heslop \& Ormerod, 2020), making investment processes easier and de-politicising development projects in the name of crisis mitigation. In short, the emergence of crisis narratives aligns the interests of private investors and developers, with those of regulators, citizens, and development-led planning systems (Colenutt, 2020). A political push-back against developers and investors has emerged, across many European cities, shaped the political and electoral landscapes as policy responses to the global housing crisis dominate election promises (Adisson \& Artioli, 2019). But the development of coherent alternative approaches that replace market-driven forms of provision remain piecemeal and isolated.

In this paper we depart from the focus of existing research to analyse how the private sector respond to, and through their actions help

\footnotetext{
* Corresponding author.

E-mail addresses: fnb22@cam.ac.uk (F. Brill), m.raco@ucl.ac.uk (M. Raco).
} 
reproduce, existing housing crises in major cities. This is important to understand because private actors play such a prominent role in delivering housing under market-led systems and reforms. We argue that the crisis situation induces further crisis through the cyclicality of how it is responded to: the crisis state of the housing market is used to justify change. The threat and speed of this change, and the focus on one particular understanding of the crisis - as supply induced - creates political risk for private actors. They respond within the constraints of the market, furthering the crisis of affordability and creating a cycle of crisis through their corporate strategies that add new spatialities to the crisis, enrol new products and attract new forms of investment. In doing so we add to theorisations of what a crisis is - how it can be and is understood by the multiplicity of actors involved in the housing crisis - by demonstrating the oscillation between crisis as an emergency with the potential to create instability and crisis as a condition that justified new approaches to development.

Whilst housing crises are by no means unique to major cities, the divergence of average incomes and house prices has been particularly acute in urban environments (Dorling, 2014). In the following analysis, drawing on in-depth research on London, we examine the ways in which private sector actors seek to navigate both the politics of crisis including the different types of crisis and related risks they generate and the complexities of working in a housing crisis. We offer four main conclusions. First, we argue that the crisis situation generates new forms of political risk for private actors who have to internalise broader tensions over the legitimation and governability of housing crises - matters that are traditionally seen as being external to the private sector and limited to fields of public policy. We show how the associated, often tension-ridden, political scrutiny embedded within crisis-driven policy is experienced differently by actors within the real estate sector, which has further entrenched the position of larger companies with more experience in understanding and dealing with the planning system as market leaders. Second, we show how the real estate sector has responded to market (and regulatory) trends, arguing that the crisis situation has been leveraged to create new places for housing development, reflecting on the political geographies of housing in London. Third, we argue the real estate sector has selectively leveraged parts of the housing crisis to introduce new investors and products to the housing system, in this we develop four types of crisis and their related political risks. Fourth, we argue these require regulatory changes and that, in garnering the necessary political support, the private sector has used the market-led crisis-driven regulatory context to further entrench their position as the solution to a crisis in which they are implicated.

\section{The rise and rise of crisis politics}

Crisis narratives have come to dominate policy discussions and broader conceptualisations of the role of regulation in the governance of cities and broader territories. As Gamble (2014: 28) notes, crisis has become 'such a ubiquitous term in modern politics that it often seems to have lost any precise meaning'. Critical writings consistently highlight how crises, from economic crises to natural disasters, have resulted in significant policy changes, with a tendency towards deregulation and corporate opportunism (Klein, 2014). As such, crisis-driven policy, whilst attempting to alleviate the inherent contradictions and crisis prone moments of capitalism, has tended to further entrench neoliberal logics with calls for 'more market' seen as a solution to market instabilities (Crouch, 2013; Jessop, 2001). This ideological work associated with the term has allowed traditional, hierarchical modes of governance to be blamed for the crises found within markets, legitimating further relaxing of regulations and ideological pursuits such as the implementation of austerity post-2008 (Penny, 2019; Wacquant, 2012; Walby, 2015). In this way, crises are presented as moments for change because the naming of a situation as a crisis performs a certain role: it provides 'disruption to the discursive and symbolic order', and warrants urgent and exceptional responses in order to resume a state of imagined 'normality' and balance (O'Callaghan et al., 2014; Žižek, 2014). And yet, as Gamble (2014:6) argues, in the wake of the GFC, attention was shifted away from more structural regulatory reforms 'because the immediate crisis has been successfully contained and many of the economic, political, and ideological challenges posed by the crash have been defused. This has made it possible to stave off calls for more radical change and a plan to return to business as usual'. Writers such as Roitman (2013: 10) similarly claim that in promoting selective uses of the term crisis, neoliberal political narratives have both 'enabled and foreclosed particular types of questions and limited opportunities for more structural reflections on the crisis-prone nature of capitalism'.

\subsection{The regulation and governance of urban crises}

Turning specifically to contemporary urban housing crises we identify four dominant ontological framings that act as the basis for characterisations of both the functioning of markets and the influence of regulatory arrangements and instruments on the delivery of new housing (see Fig. 1). First, there are supply-side narratives that view housing crises as expressions of a lack of available housing to meet growing demographic demands. The economies and populations of major cities have grown markedly during the 2000s, but the supply of new housing, it is argued, has failed to match these increases resulting in a crisis of affordability and availability. This form of market failure is allegedly a consequence of overly restrictive and out-dated planning polices, unable to adapt to the modern market-driven needs of private sector investors, developers, and house-builders. Viewed in this way, the reductionist solution to the crisis is de-regulation of housing markets and planning systems, to bring supply back into equilibrium with growing demands (Storper and Rodriguez-Pose, 2020). Private sector actors, it is imagined, will shift their activities to meet new market opportunities and correct the supplyside deficit. The only restriction on this, advocates claim, is the politicisation of planning systems and the power of organised interests to block new developments. Such narratives underpin the policies of supranational bodies such as the World Bank and IMF (Amirtahmasebi et al., 2016), influential industry literature and journalistic accounts (Williams, 2020), and a school of academic writers for whom planning constraints (such as the designation of greenbelt land) limit much needed supply (Cheshire, 2019).

Second, housing markets are seen to be in crisis when there is a lack of demand for new housing and a decline in market activity that reduces incentives for investors and increases financial risks. A range of writers have highlighted the unattractiveness of residential property as an asset class vis-à-vis other more liquid assets (see Baum and Hartzell, 2012; Crosby and Holgersen, 2014). In economic recessions house prices can fall, as happened in the early 1990s in much of Western Europe and in the immediate aftermath of the Global Financial Crisis of 2008. A drop in demand filters through to a fall in investment and new supply. If crises are viewed in this way, then the political response can become focused on mechanisms to maintain demand - such as subsidising or directly providing finance for individuals to purchase homes or through the direct financing of new (counter-cyclical) housing. In many western countries, especially the UK during the 2000s, governments have been willing to pursue the former, through welfare payments or 'help to buy' subsidies to individuals, but for ideological reasons have opposed the latter and allowed only limited state-financed house-building.

Third, there are also other elements of urban housing crises that relate more closely to failures of governance and regulation. The presence and persistence of long-term narratives of a 'housing crisis' generates a wider legitimacy crisis for governments and state actors. Policymakers face growing political pressure to act. In Schapf's (1992) classic formulation, they are unable to generate sufficient, visible outputs (such as new housing) to legitimate their actions amongst voting populations. However, many governments are caught in a bind, especially where welfare systems have been in retreat. On the one hand, tackling housing crises involves a clear policy outcome and reference point for success - to 


\begin{tabular}{|c|c|c|c|c|}
\hline Type of Crisis & Core Expression & Policy Response & Temporality & Risk generated \\
\hline Supply Crisis & $\begin{array}{l}\text { - Lack of available housing to meet } \\
\text { market demands and population } \\
\text { growth } \\
\text { Rising prices and reduced affordability } \\
\text { as lack of filtering through the housing } \\
\text { market } \\
\text { Constraints on the capacity of private } \\
\text { and institutional investors and house- } \\
\text { builders to build more units } \\
\text { - Fiscal limitations on the ability of public } \\
\text { authorities to build housing directly }\end{array}$ & 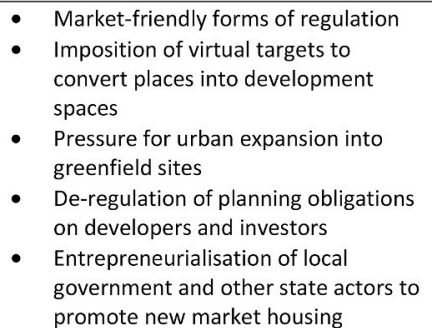 & $\begin{array}{l}\text { - Structural and long-term } \\
\text { generational crisis } \\
\text { - Short-term events } \\
\text { exacerbate crisis, rather } \\
\text { than creating it } \\
\text { - Lack of flexibility in } \\
\text { housing infrastructure } \\
\text { reducing its } \\
\text { responsiveness to short- } \\
\text { term changes in demand }\end{array}$ & 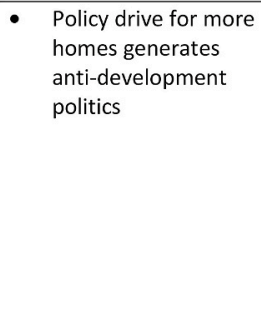 \\
\hline Demand Crisis & $\begin{array}{l}\text { - Lack of market activity leading to falling } \\
\text { prices } \\
\text { - Less incentive for investors and } \\
\text { developers to view housing as a priority } \\
\text { - Housing become unaffordable, with too } \\
\text { few consumers able to meet price } \\
\text { demands }\end{array}$ & $\begin{array}{l}\text { - Use state funds to support individual } \\
\text { buyers (mortgage subsidies) } \\
\text { - Attract inward investment from high- } \\
\text { income individuals/institutions }\end{array}$ & $\begin{array}{l}\text { - Strongly shaped by } \\
\text { events and short-term } \\
\text { cycles } \\
\text { - Long-term demographic } \\
\text { and economic shifts } \\
\text { change the character of } \\
\text { demand in ways that } \\
\text { require systemic changes } \\
\text { in supply }\end{array}$ & $\begin{array}{l}\text { - } \\
\text { Existing real estate } \\
\text { obsets become } \\
\text { obsolete and lose } \\
\text { value } \\
\text { Increasingly difficult } \\
\text { to attract new } \\
\text { investment into } \\
\text { housing and } \\
\text { residential property }\end{array}$ \\
\hline $\begin{array}{l}\text { Legitimacy } \\
\text { Crisis }\end{array}$ & $\begin{array}{l}\text { - } \quad \text { State system seen to be failing to tackle } \\
\text { housing crisis of affordability for } \\
\text { particular groups } \\
\text { - } \quad \text { Output-centred legitimacy } \\
\text { - } \quad \text { Rising value of housing assets also seen } \\
\text { as a political priority }\end{array}$ & $\begin{array}{l}\text { - Greater focus on planners and state } \\
\text { agencies to boost housing unit } \\
\text { numbers } \\
\text { - Simultaneous concern that policies } \\
\text { should not reduce the value of } \\
\text { housing assets }\end{array}$ & $\begin{array}{l}\text { Linked to election cycles } \\
\text { and the (in)ability of } \\
\text { governments to tackle } \\
\text { housing problems faced } \\
\text { by different groups }\end{array}$ & $\begin{array}{l}\text { - Market actors lose } \\
\text { their legitimacy to } \\
\text { influence policy }\end{array}$ \\
\hline $\begin{array}{l}\text { Governability } \\
\text { Crisis }\end{array}$ & $\begin{array}{l}\text { - Creation of governance problems that } \\
\text { are beyond the capacity of existing } \\
\text { institutions to resolve } \\
\text { Growth of international flows of } \\
\text { finance and regulation that limit the } \\
\text { capacity of territorial governance } \\
\text { arrangements }\end{array}$ & $\begin{array}{l}\text { - Multiple policy responses across a } \\
\text { range of fields } \\
\text { - Continual creation and recreation of } \\
\text { policy initiatives to take control of } \\
\text { housing crises } \\
\text { - Policies driven by a state of } \\
\text { exceptionalism in order to bring } \\
\text { about a functioning 'normality' in } \\
\text { housing markets }\end{array}$ & - On-going & $\begin{array}{l}\text { - } \\
\text { private actors (fiscal) } \\
\text { added to planning } \\
\text { processes } \\
\text { - Expectation that } \\
\text { private actors are } \\
\text { able to 'govern' and } \\
\text { organise urban } \\
\text { development } \\
\text { processes }\end{array}$ \\
\hline
\end{tabular}

Fig. 1. Types of crisis and risk generated (author's own).

make housing more affordable to a wider range of groups and meet identified housing needs, possibly through a lowering of asset values. On the other hand, governments are under pressure to maintain house prices for those who benefit from the presence of a housing 'crisis', especially land-owners and home-owners. Writers such as Crouch (2013) argue that because individuals are reliant on generating income for their own welfare - a form of privatised Keynesianism - public policy must boost asset values and house-prices further. This tension underpins public policy responses, especially in countries in which welfare programmes are in retreat. Added to this is that the housing construction and financing sector is economically significant and its financial and viability needs have to be taken into account in the delivery of any new policy, even if their activities help to further fuel a crisis of supply or demand for citizens and consumers.

Finally, housing crises are also underpinned by a crisis of governability or what Jessop (2002: 180) identifies as 'the question of whether a socially or discursively constituted object of governance could ever be manageable, given the complexity and turbulence of the material, social and spatiotemporal conditions in which it is embedded'. In other words, crises are also generated by over-simplistic characterisations of the functioning of housing markets and the transformative potential of regulatory reforms. Within such framings, governance problems such as affordability, can become 'ungovernable' if they are set up in a reductionist manner and/or if they establish targets and proposed solutions that are beyond the capacity of individuals and institutions to address. At its most influential, a crisis of governability triggers a set of emergency policy responses that are, paradoxically, considered to be necessary in order to maintain a degree of 'normality' or what some, following Poulantzas, have termed a 'state of exceptionalism' (Jessop, 2002; Žižek, 2017). If crises are persistent, then this exceptionalism can become the norm and questions over whether a housing crisis can be resolved remain unanswered as the core focus of what a crisis consists of expands to incorporate multiple and sometime contradictory meanings.

Looking specifically at countries such as the UK, the majority of research on its urban housing crises has focused on political responses (Heslop and Ormerod, 2020). Whilst there exists a diversity of policy responses, research has emphasised the primacy given to supply-side approaches to alleviating housing market pressures (Gallent et al., 2018). Expedited policy and new mechanisms of governance have removed spaces for civic engagement, giving private actors and corporations new powers and freedoms to deliver urban development and housing. The naming of the crisis acts as a powerful tool for constructing political mobility and initiating change (Madden \& Marcuse, 2016). Following this logic, the housing crisis (in its multiple forms) has created new landscapes of regulation that are favourable to the real estate sector and have encouraged selective investment into high-return housing and inflated costs for all citizens (see Rolnik, 2019).

However, there are two significant limitations in this broader research. First, the housing crisis, and political responses to it, vary significantly, both in terms of political agendas and in concrete market dynamics and processes (Williams, 2020). The four types of crises identified in Fig. 1 exist to differing degrees in different contexts and are shaped by geographically variegated planning and housing histories, spatial patterns of growth and inequality, and dominant approaches to housing and welfare. The claim that regulatory structures are inexorably moving towards the introduction of developer/investor-friendly policies underplays the very real conflicts that exist within political projects and the tensions within crisis definitions and (policy) prescriptions (Brill and Robin, 2019). In reality, a lack of coherence across different state bodies and the legitimacy and governability crises highlighted above, can generate new barriers to private sector activity and/or politicise their actions in new and more intense ways (Immergluck, 2011). For instance, broadly-shared perceptions and narratives of crisis have also triggered critical responses from city and local authorities in a number of contexts, 
with increasing pressure from civil society groups to introduce measures to limit cross-border flows of real estate investment or to challenge new projects that generate less affordable and/or lower quality supply (Shelter, 2019). Thus, whilst there may be a push from some national governments and supra-national agencies to liberalise market flows, the place-based nature of real estate investment enables local actors to exert a degree of control and/or resistance and this contributes to a wider crisis of governability. The narrative of crisis can, therefore, politicise urban planning deliberations in multiple ways (Heslop and Ormerod, 2020) and in doing so generates new forms of political risk for private actors seeking to acquire approvals for their proposed projects. This risk and its relationship to crisis has been relatively under-explored in geography and urban studies.

A second limitation in accounts of crisis is their state-centric focus and a lack of attention given to the heterogeneity found within the private sector, that is often characterised under the broad umbrella of real estate professionals (see Özogul and Tasan-Kok, 2020). They are assumed to possess shared interests, outlooks, ethical frameworks, and political capabilities (Riles, 2018). And yet, the highly localised nature of urban development and the place-specific character of urban expertise, demonstrates the necessity of understanding how regulatory and political environments interact with the specifics of local development professionals (Robin, 2018). A growing body of work emphasises the embedded nature of real estate practices and the importance of local knowledge in allowing actors to navigate increasingly complex regulatory and market environments (Halbert \& Rouanet, 2014; Raco et al., 2019). It demonstrates the importance of paying attention to the discursive impacts of crisis situations - attending to the ways in which they shape the strategies of stakeholders responding to particular political environments (Robinson \& Attuyer, 2021). Understanding perspectives within the real estate sector is especially significant as crisis-driven policy reforms are seeking to mobilise, enrol, and co-opt their resources and expertise in a collective effort to tackle supply-side shortages. Responding to this, departing from the dominant political economy approach, we focus on a more grounded analysis of how descriptions and prescriptions of the housing crisis shape the strategies of private actors, particularly in major cities such as London, to which we turn to next.

\subsection{London's housing crisis}

London is experiencing an affordability and quality related housing crisis which is dramatically and negatively impacting the majority of residents, the flexibility of the city's labour market, and the availability of key workers in the welfare sector (Dorling, 2014). Understanding the housing crisis in this way - as something that exists for many London residents - and putting it into conversation with the discussions of crisis above demonstrates how it 'hard-wired' into housing policy (Colenutt, 2020, p. 14). This is particularly evident in a recent UK government paper on Fixing the Housing System which focuses on land delivery, speeding up construction after planning permission and diversifying market products. The issue of housing supply is seen as the root cause of the housing crisis because 'This country doesn't have enough homes. That's not a personal opinion or a political calculation. It's a simple statement of fact'. But London's housing crisis is more complicated than a lack of housing supply, it is also tied up in problems of 'huge cheap debt' (Ryan-Collins et al., 2017) and affordability, as acknowledged by the former Prime Minister: 'Whether buying or renting, the fact is that housing is increasingly unaffordable' (DCLG, 2017, p. 5). And so, the framing of the UK's housing crisis is constantly shifting, from the 'housing emergency' of housing charities to the affordability crisis used in commercial reports. This situation 'isn't a looming crisis, a distant threat that will become a problem if we fail to act. We're already living in it' (DCLG, 2017, p. 15).

London's housing system has exhibited characteristics of a crisis for a long time, but more recently the situation has been exacerbated by financial deregulation and changing demographics. The housing system is governed by a complex four-tier system around which different agendas and interests coalesce: national planning policy; city-level planning guidance from the Mayor and Greater London Authority; 32 local authorities (or boroughs); and neighbourhood forums based on local community-led referendums. National policy was substantially reformed in 2012 with the introduction of the National Planning Policy Framework [NPPF] in response to what was seen as a system hindering the limited supply of land and housing, which contributed to the housing crisis. The NPPF entrenches a presumption in favour of development, particularly on brownfield land. When bringing forward a site, developers are required to deliver affordable housing to account for the extreme undersupply at the bottom of the market, where the level of contribution made by the private sector is dictated by a viability calculation and included in what is referred to as a section 106 agreement. In London, the Mayor has sought to tackle the housing crisis is a different manner: favouring what he terms a threshold approach and 'bringing in' developments for examination where either insufficient affordable housing has been provided or where local authorities have declined an application, but the Mayor supports it. These two layers of governance shape the wider context, but it is in local authorities, and in neighbourhood-based planning, where approval decisions are (primarily) made. The variability within and across London is considered an important determining factor in where developers bring forward sites since viability negotiations vary hugely across London (Ferm \& Raco, 2020).

The literature on London's housing crisis is extensive but misses the critical reflections outlined above: it fails to analyse the ways in which crisis is understood, mobilised, and institutionalised as a set of embedded framings and institutionalised responses from real estate professionals; and the way in creates risk (see Fig. 1). In the following sections, we assess how the private sector engages with both the political and regulatory responses to London's housing crisis and the challenges of working in a crisis-prone property market, that is subject to constant regulatory reform and broader crises of political legitimacy and governability as set out above. The research was a three-stage data collection and analysis process. We began with discourse and documentary analysis of key commercial actors' research reports. Organisations were selected based on their size, therefore all the available published residential-focused reports by Savills, JLL, CBRE and Knight Frank were analysed. The sample included over 300 reports, which were collected both online and from their headquarters in London. For each document we coded for 'framings', 'use of crisis', 'regulatory agendas', 'corporate changes' and 'spatial strategies'. These codings originated in preliminary project interviews. Themes which emerged from the discourse analysis were then used to structure interviews with researchers based in these organisations, to better understand the purpose of the reporting. The second stage was data collection and sorting from a commercial database produced by Real Capita Analytics (RCA). This data included transactions from 2008 till the present day of properties or sites worth over $\$ 5$ million. This data and the associated RCA reports were used to trace investment and development patterns over time and identify key professionals for interviews.

The final stage was interviews with 50 real estate professionals in London including: investors (10), developers (a mix of residentialfocused (4), large housebuilders (4) and smaller niche developers (4)), brokers and consultants (17), property sector lobbyists (5) and analysts (6). We made a deliberate effort to reflect market characteristics: speaking with people from firms that are representative of trends i.e. a balance of smaller and larger companies within developers but targeting the 10 largest investors based on transaction volume. The majority of the interviewees (48) were senior members of staff within their particular organisations. Our interviews ranged in length from $40 \mathrm{~min}$ to nearly $2 \mathrm{~h}$ and addressed: interviewees' perceptions of the residential market; their strategies and aims within it; their particular role within the housing market; and the impact of regulations and governance on their 
strategies. After the first 5, an additional line of enquiry to explicitly address the role of the crisis was added, reflecting the repeated nature of crisis narratives in the first interviews.

\section{Political risks, crisis-driven policy and the political geography of London's real estate sector}

Narratives of crisis permeate understandings of core regulations amongst real estate firms, and they are understood to generate a degree of (potential) political risk. In this paper we understand political risk to be the risk to project delivery (and ultimately financial gain) created by the political environment, in a broadly conceived sense. This manifests as the threat of regulatory change - from changes in tax to a change in operational practice regulations - and emerges in response to the perception that the crisis creates an emergency state. We argue that the cyclical nature of the crisis-risk relationship is at the centre of understanding how private sector actors respond to the housing crisis because it creates both new opportunities through a re-purposing of the city's planning systems to prioritise house-building and supply, and it generates new challenges as private sector actors are required to engage in a politics of legitimacy-building and governability.

All our respondents noted broader shifts in policy, especially at a national level, towards more delivery-focused forms of policy but, associated with this, a crisis of governability or the parallel introduction of a growing number of regulatory requirements, costs and potential constraints implemented to incentivise and prioritise new market-led construction. We found interviewees made crude distinctions between approaches at different spatial scales, with demand-centred reforms to tackle the housing crisis largely operationalised at a national level; and policies depicted as limiting the market's capacity to deliver, typically attributed to the Mayor of London, local boroughs, and the communities they represent. Real estate professionals must navigate the tensions between these policies and admitted that the widely-perceived presence of a supply-side housing crisis represented "a double edged sword - it can bring housing issues to the fore ... can be helpful because it gives a sense that everything has to be done now" (Lobbyist 2, 2020) and that can inspire new actors to enter the market in the hope of delivering opportunities for profit to their shareholders. But without "stability for long-term investment" in terms of the policy landscape, many actors struggle to navigate a highly-politicised crisis-driven policy environment subject to constant change and reform (Lobbyist 1, 2020). In this regard, our analysis supports the idea that the naming of the housing crisis as such initiates new policy measures and particular forms of political mobilisation (Heslop \& Ormerod, 2020; Madden \& Marcuse, 2016), but we depart from existing research to show how such policies then translate into political risks experienced as crises of governability and legitimacy for real estate professionals on the ground, which can limit the stimulating effect of policy. To address perceptions of political risks, we draw from recent work that applies critical risk studies through a geographical lens to highlight how the political climate is interpreted as a risk by private sector actors (see Brill \& Robin, 2019). As such, political risk is inherently tied up in profit and loss calculations i.e. financial risk, but following existing approaches we differentiate the political risk from other forms of risk such as community risk (ibid.) or void-risks.

Real estate advisors highlighted how the UK government's flagship demand-led housing policy, Help to Buy, which provides subsidies to those unable to afford their first home, functioned as a catalyst for development and bolstered house sales. The buoyancy of the housing market and the sector's capacity to sustain business despite wider economic concerns was directly attributed to this crisis-targeting policy: 'The lower-end of the market, especially when supported by Help to Buy, has remained active' (JLL, 2017a). For advisory firms such as JLL, measures to support market demand in reaction to the crisis were key for their clients' capacity to maintain relatively high and stable profit margins because it stimulates investment and justifies their supply strategy: 'The equity loan element of Help to Buy, has proved a success ... The mortgage guarantee scheme helped 75,000 onto the ladder' at specific price points (JLL, 2017d). Importantly, for understanding the emergence of Help to Buy and its positive reception by real estate professionals, is that it targets a group of buyers who find housing unaffordable without assistance. This idea was repeatedly referred to in interviews, with one developer noting that "you've got this huge middle market where people are in good jobs but they can't access the housing they want". But at the same time, Help to Buy also provided price floors for developers. Other regulatory changes, such as the introduction of the relatively flexible NPPF and the requirement for local authorities to plan for increasing numbers of new houses, were also seen as positive steps that provided some degree of certainty.

However, at the same time as generally supporting such regulatory changes, interviewees also raised concerns over the impacts of the politics of crisis, fearing it might bring about radical changes that could shift development models and financial viability calculations at relatively short notice. As such, interviewees noted it was essential to understand how regulatory responses to the crisis develop. In response to how their firm addresses the crisis situation, one interviewee replied that their firm now: "obsess over what goes on politically" (Analyst 4, 2019). For them, it is essential to actively engage with the process of policy development and to maintain a deep understanding of how it might happen.

This fear of regulatory change was compounded by what an interviewee noted as widespread misunderstandings of the sector, with diverse firms "lumped together - but in reality some are less and more knowledgeable, some are funders and investors, some are specialists in mixed development, some do housing schemes in bulk or niche". Regulating development activities is therefore a complex task and ostensibly 'pro-market' reforms to tackle supply-led crises have differential impacts across the sector (see also Brill and Robin, 2019). For instance, whilst the Help to Buy scheme has been beneficial for volume house-builders, smaller firms or those specialised in highly skilled and niche forms of development have been unable to capitalise on it (Developer 6, 2019).

At a city level, London was widely perceived to be an increasingly 'difficult' market in which to invest and make profit, a finding that was in contrast to much writing on global cities that sees the city's real estate system as open and highlights how it is accessible to a growing class of international investors, buyers, and operators (Atkinson, 2019). In particular, interviewees highlighted how policy-makers were increasingly concerned about the (output) legitimacy of their failing actions to tackle the housing crisis and how cumulative failures were generating new tensions around the governability of the sector as a whole. There was widespread concern over the increasingly 'onerous' policies of the Mayor, the tensions between national and city policies targeting the housing crisis, and the burdens this placed on developers in terms of needing sufficient knowledge to navigate the complexities of the crisis-driven situation. As a result, mirroring response to national crisis-inspired policy, advisory firms and large developers are more capable of navigating the system and, therefore, able to make profit. A representative of the Home Builders Federation, for instance, noted that:

"London is different to elsewhere and it is a very complex city for housebuilders. It possesses a high number of brownfield sites are complicated and difficult to develop. In addition to planning complexity, with multiple scales of decision-making, it is also a global city attracting lots of investment from overseas. The UK's major house-builders are mainly specialists in large-scale development, but London's brownfields require different knowledge".

The crisis-focused nature of housing governance in London, especially the threat of Mayoral policy changes, was depicted even by large and experienced firms as difficult to navigate and consider within investment plans. Respondents claimed they faced unfair levels of political 
scrutiny and that they were required to legitimate their actions, by providing social infrastructure and 'affordable' housing to meet crisisdriven demand (Developer 12, 2019).

In interviews and the property industry literature, the same critical messages of London's political environments were evident: 'the volume of construction activity is high by historic standards but, with planning applications slowing sharply, driven in part by the Mayor's firmer stance on affordable housing provision, the medium-term supply pipeline is less certain' (JLL, 2018b). Indeed, and as evidenced in this quote, for many real estate professionals, the Mayor's position was directly referred to as inhibiting real estate actors' capacities to address the housing crisis. Advisory firms argued that '[Mayor] Sadiq Khan's more onerous and firmer stance on affordable housing provision, which includes the important viability review mechanism, is undoubtedly a crucial factor in this slowdown. It is also having the desired effect of changing the planning and development landscape' (ibid., emphasis added). For interviewees, the tensions between a national government promoting industry-led solutions, and a Mayor attempting to force developers to deliver larger amounts of on-site affordable housing, presented a political risk they had to calculate in planning processes. The contradictions within policy frameworks led to "unintended consequences, because of a lack of understanding of how different silos work across the private sector work" (Researcher 1, 2019). This, many interviewees argued, required them to actively engage with the politicised nature of the crisis and in particular to acquire "different knowledge" about development processes (Lobbyist 3, 2020). This includes understanding the flow of policies brought forward, especially around value-capture, which were considered a key source of potential political risk. As one investor noted: "there is a risk that [they] introduce policy with good intentions ... [but] they become a hindrance to progress by trying to be prescriptive about certain elements".

The political risk induced through the multi-tier system outlined above was further compounded by local boroughs' markedly different approaches to development, where each possess specific histories of leadership and approaches to planning and developers. Boroughs are in the process of drawing up formal Local Plans that set out priorities and require real estate professionals to adapt proposals to be 'in conformity' locally, whilst still complying with city-wide and national regulations. This multi-level situation means that the housing crisis is viewed through specific local conditions and circumstances, yet must cohere around a specific wider set of objectives. In the words of one experienced consultant who advises house-builders:

"the difficulty is that there is no categorisation that can easily be made and local authorities are always shifting their views about what matters. All boroughs have their own, very individual approaches. All are constantly negotiating with the Mayor and their local communities and trying to meet national priorities ... it's a muddle for developers!“.

Or as one senior consultant commented:

"London is a very particular place to do viability work as the standard 'greenfield' models developed by government, especially in the NPPF, don't apply - so there is enormous complexity even in discussions over the same site, let alone the same borough. Plus the new thresholds and expectations over $\%$ of delivery are centre-stage in all discussion. And on top of that affordable housing is a much more political issue for boroughs and the Mayor than anywhere else".

What is important to note is that the complexity stemming political risk did benefit some real estate professionals, especially well-resourced house-builders and a growing assemblage of consultants. Those working at consultancies explained that their technical capacities and experience in London made them sought-after amongst developers. This perceived value, in terms of bringing new expertise into a project, was recognised across the industry: "there's plenty of expertise ... if you see a gap in the market and someone comes in, you can be sure that all of the consultants and business gear up really quickly to be able to deliver ... it's planning we load all of this affordable housing onto the market ... it's not viable, you can't make a profit from it, you can't deliver it" (Developer 2, 2019). Advisory firms, ranging from development consultancy through to private planning practices, are therefore able to leverage the crisis situation to increase the value of their knowledge. Such expertise is expensive and therefore more profitable firms, which in the London case is largely the bigger volume housebuilders, are more able to acquire the knowledge required to navigate the political risks. As one consultant reflected: "the geography of London is difficult to understand [...] but this gives more opportunities to big players who can deliver" informed by their army of consultants. In the next section, we turn to how the sector has developed tactics and strategies of diversification to work with and benefit from a market 'in crisis'.

\section{Putting the housing crisis to work and operating in a market} in crisis

"let's not get bogged down in the word 'crisis' and whether something that is perennially a problem can still be called a crisis, but it is, perennially, a problem but [...] you [can] recognise a problem as an opportunity"

In this section we identify and discuss three main ways the sector responds to the housing crisis beyond their navigation of the political risk induced by policy as identified above. First, the spatial targeting of new sites for investment; second, the introduction of new types of 'products' or tenure types; and third, the attraction into the market of new types of investors. We argue that each of these occur because the crisis has driven up profitability unevenly and therefore drawn in new spaces and types of actors. These actors though, we argue, require regulatory support and legitimation and discursively leverage the crisis situation to their own benefit whilst co-opting the languages and problems of the housing situation. As such, the lens of crisis proves a fruitful conceptual framework for understanding the underlying dynamics generating commercial changes. We find the multiple forms of crisis outlined above: whilst the government phrasing prioritises the supplyside narrative, the utilisation of the crisis state by private sector actors enrolled the problems of demand, legitimacy and governability but helps to generate outcomes that lead to the supply of housing types and tenures that exacerbate a crisis of supply.

\subsection{Using crisis narratives to re-shape spatial imaginations of investment}

The first way in which the crisis narrative is leveraged is to shape new spatial imaginations of housing development patterns across the city, challenging where is depicted as a 'good' or 'up and coming' investment location and diversifying the locations for new investments. There has been a particular focus on the seeking out of what JLL call 'ordinary' locations, away from central London and on sites that were previously seen as non-prime locations. In this regard, crisis reflects, (re) creates and manifests with a spatial impact. For example, there has been a concerted attempt to redefine London's 'East' and to use new developments to create more affordable types of housing for middle income earners and key workers. As has been well documented, parts of east London have experienced high levels of gentrification during the 2000s (Watt, 2019). However, looking at the use of crisis narratives by advisors in real estate, we see how the idea of a rent gap is leveraged to attract investors to specific areas: 'The area is still more affordable than most parts of London but the gap is beginning to close as Londoners seek value for money and higher growth potential locations' (JLL, 2017a). In this way, what is defined as a 'peripheral' location changes: 'The fringes are broadening to include more areas' (JLL, 2018a). This is an explicit leveraging of the crisis of affordability: 'With affordability becoming increasingly stretched, many first-time buyers are being forced to look 
further afield to find suitable accommodation, while existing homeowners wishing to trade-up are also having to look outward. Parental support for those fortunate enough 'ordinary' people will also boost demand, especially in outer London' (JLL, 2014).

During interviews with those working to "push out into what we're calling the East London corridor .... following the main arterial routes out of London", interviewees explained that this development trajectory had become viable because of "affordability - I know it's a relative term - property - in the eastern corridor, it is more affordable for more people" (Advisor 1, 2020). Acknowledging that development in the centre is "hard" in terms of the challenging politics of development, she also noted that the crisis of affordability means "in the east there's no comparison, to me it seems there's no comparability in terms of value for money" (ibid.). The recognition that London's housing crisis is having a direct impact on the ability of buyers to purchase housing has encouraged this shift towards developments in more affordable locations.

The trickle-out effect was evident more broadly in interviews where peripheral locations were noted as more viable because the crisis has driven up costs in the inner London boroughs. For example, the UK's biggest housebuilder Barratt Developments have 3 central or inner London sites, but 9 outer London sites (RCA, 2020). Central locations are increasingly problematised (Barratt Developments, 2017) and a more suburban focus has been pursued in light of 'strong sales rates' and 'positive price trends' which translate to profit for them (ibid.), but contribute to a crisis of supply for would-be buyers. In this regard the housing crisis shapes the corporate strategies of key actors in London's housing delivery system, in terms of their justification for expanding their market beyond traditional, central locations, which also serves to stimulate a wider spatiality of the crisis as new areas become unaffordable for most people.

\subsection{Using crisis narratives to create new products}

The second way crisis narratives influence corporate strategies is to justify diversification into new housing products and types. Employees of some of the biggest property firms were explicit in stating that narratives of crisis were used strategically to create market opportunities. To legitimise diversification firms mobilise government statistics around the housing crisis, such as the 'need' for 300,000 new homes annually - a target frequently referred to in interviews. Interviewees then argued that these products were key in alleviating the crisis situation, arguing that they and their expertise are essential for addressing growing and shifting housing demands. Such examples demonstrate the close interrelationships between selective narratives of the housing crisis, public policy interventions with their focus on the generation of new supply at all costs, and the private sector responses.

Two frequently drawn upon examples of 'new products' in our interviews were Build-to-Rent [BTR] and the idea of micro-living. There are now 60,000 new BTR units in the pipeline across London and it is consistently legitimated as a solution to the housing crisis in terms of both providing enough rental properties and delivering quality in the private rental sector (Brill \& Durrant, 2021). Yet it has developed, from the outset, as an asset rather than as a form of housing. As one investor responded when asked if the housing crisis attracts investors:

"I think, absolutely. If you look at the size of the funds that have been raised by the likes of M\&G and the amount of capital that's trying to get into the space .... I think there was a survey the other day that said there's something like $£ 11$ billion chasing build to rent opportunities in the UK at the moment, so there's an enormous amount of capital trying to get in ... you've got to look at real estate as an asset class in itself" (Investor 6, 2019).

BTR seems to provide a way of generating housing that cuts through the crisis of governability that afflicts other housing sectors. Or in the words of the British Property Federation 'the development model for
Build to Rent differs from traditional build for sale and so should be treated differently reflecting the different development economics' (BPF, 2019: 1).

iFor real estate professionals, crisis narratives can be put to work to legitimise their political strategies as policies are developing. In this respect, we see how mitigation work extends beyond directly-profit orientated activities to include wider lobbying efforts to create a supportive (political) institutional context. Or in the words one BTR investor "the government has a big responsibility to encourage development of BTR ... because it's one of a number of solutions to help solve the housing crisis" (Investor 6, 2019). In this respect, both our interview data and the commercial analysis point to the ways in which real estate professionals' regulatory aspirations are rooted in understanding the commercial and political landscape, such that their modelling and costings are predictable and therefore more guaranteed; rather than seeing supportive as encouraging investment or entrepreneurial as with more classical governance literature on the entrepreneurial state.

The second major new product, micro-living, was particularly endorsed in commercial reports. As JLL argue 'Modern purpose-built micro homes $[\ldots .$.$] can provide an improved option for people' because$ more smaller properties would enable developers to 'price in' 150,000 currently excluded potential buyers .... and forms a crucial part of the solutions to the housing crisis' (JLL, 2017b: emphasis added). To justify regulatory support, JLL draw on selective statistics to highlight the scale of the housing crisis, noting that 150,000 homes are currently breaking minimum space requirements and that these are a vital part of the broader housing system. This legitimation tactic is used to try to shift the policy context to be more supportive and stable. For example, The Adam Smith Institute used such arguments to call for neo-liberal planning reform: "Young and economically active, many would rather live in a smaller unit close to their workplace and the world-class entertainment a city like London offers rather than in a bigger suburban flat [...] Hence, for them micro-housing could be a suitable option" (Kichanova, 2016). It is then employed by real estate actors to advocate for new developments or products. Indeed, JLL position micro-living as a product which would specifically cater to those most challenged by the housing crisis, millennials:

'Different household types have very different requirements for their homes. A pensioner may well say they need a bedside cabinet to put a lamp, clock radio, glass of water, family photo and a book. A millennial meanwhile is likely to be content with enough space to put a glass of water and a mobile phone, the latter of which doubles up as a lamp, alarm clock, photo album and reading device' (JLL, 2018b).

The push to diversify products to meet the housing crisis leads to the third impact: seeking out new types and classes of investor who are drawn to the new 'products' or asset classes.

\subsection{Using crisis narratives to attract new investors}

A range of new forms of finance has entered London's housing system (Beswick et al., 2016), from short-term orientated firms seeking distressed assets, through to institutional investors with longer term 'patient capital' approaches. In our interviews we found that real estate professionals used the crisis to justify why these new forms of finance or investment had arrived, why they needed regulatory support and how they would contribute to the alleviation of the housing crisis. In general, across our interviews, actors explained that at the core of new investor interest was how the crisis of affordability translates to increased revenue, as one advisor reflected, "investors are attracted to crisis as long as there is profit to be made" (investor 7, 2019). The arrival of new investors has been particularly acute in the case of new property forms.

Importantly, the sense of 'housing crisis' and the narratives around London's property market were perceived to have attracted different investors depending on the particular risk profiles of new projects and 
the potential investors see in the crisis as a moment for exploitation. As one prominent investor noted in interview:

"So is private equity attracted to housing because of the crisis? Well, Blackstone are one of the biggest private equity guys [sic.] and they can see that there is shortage, where there's shortage there's pricing benefits and demand, so it makes sense to try and meet that supply, so yeah, I don't think the new groundswell of cash into it is chasing a quick buck because of an under supplied housing market [...] Private equity will always be attracted to producing profit where profit is available and if someone's looking to create long term assets and there's a development aspect to it, then they'll play in that world" (Investor 6, 2019).

As is evident, the crisis is invoked strategically by advisors as a platform for greater profiteering. For one adviser, the perception of a housing crisis "absolutely shapes how investors see London" and his firm promoted this as "a problem, is an opportunity". These opportunities emerged because London's property market was seen as "extreme ... out of balance, with supply perennially behind demand".

Understanding the housing market as suffering from market failure, paradoxically, is attracting new types of investment from institutions looking for longer term returns and seeking to overcome the traditional limitations associated with residential investment. As is evident in the way in which private sector actors have responded to the crisis, solving the (affordability) crisis requires a greater understanding of how the housing crisis has shaped the politics of development.

\section{Conclusions}

This paper draws on evidence collected from real estate professionals in London to argue that the role of private sector actors, working in specific crisis-laden urban contexts, remains relatively under-discussed, despite their fundamental role in the production and reproduction of crisis conditions. Under delivery-focused planning reforms, market actors are expected to take up new opportunities and build more housing supply to meet growing demands. This, as we show, has been done with little regard to how the sector functions and/or what roles and wider responsibilities real estate actors are prepared to adopt. This lack of attention is true of both market-led policy frameworks and critical political economy writings that equate neo-liberal deregulation with the empowerment of the real estate sector and present the current conditions of housing markets and policy environments in major cities as optimal for value extraction. The London case broadens understandings of the impact that conceptualisations of 'crisis' have on urban planning practices and how these influence and shape processes of contemporary development (see also Heslop and Ormerod, 2020). We demonstrate how different professionals within the sector respond to both the crisis itself, and the resultant policies, across different political scales. We offer four main conclusions.

Firstly, we demonstrate the ways in which the urgency induced by the housing crisis has created policies that often conflict with one another, which in turn creates political risk for real estate actors. This risk is differentially experienced by those involved in bringing forward residential developments in London, where the bigger housebuilders are able to leverage their economies of scale and experience to navigate the complex political situation. In contrast, smaller housebuilders have left the city, finding the politics of development too challenging. This entrenches a relatively oligopolistic market where a few, large firms are able to dominate London's housing provision providing limited variety in products. Moreover, in light of the political complexity inherent in the crisis-driven responses by the different levels of government, advisory firms are more valuable within the real estate ecology (Henneberry \& Parris, 2013). This adds to existing research on the politics of risk (Brill \& Robin, 2019; de Maghalaes et al., 2018) by demonstrating how it functions in a more systematic way to shape the markets that develop.
Second, we show how the crisis situation reshapes three key corporate strategies that ultimately influence the development of housing. Firstly, the spatiality of development changes as more peripheral locations become preferred sites for development, both in terms of the affordability-driven 'trickle out' of house prices pushing people further from the centre, and the politics of development with lower land values meaning development is considered more viable. This highlights how the politics of crisis response, heavily linked to the particularities of the housing needs of local authorities, shapes where developers are willing to bring forward sites. Such an understanding better informs the geography of urban development, particularly the geography of a viabilityled crisis-informed policy landscape (Ferm \& Raco, 2020). Secondly, we argue that, in addition to reshaping where sites are viable, the crisis narrative is discursively used to bring new products and investors into the market. Focusing on Build to Rent, micro living and institutional investors, we show how the particularities of rising rental values (the affordability crisis) and the lack of adequate supply (the crisis of quality) are capitalised by real estate professionals to position market-led situations as the solution to the housing crisis. This demonstrates the political power of crisis narratives in informing market actions. Finally, building on the idea of crisis narratives informing market-making strategies by real estate professionals, we show how the construction of new markets, in terms of new geographies of products and investors, requires a supportive political environment. In doing so we argue that each of the changes to the market we demonstrate leaned on the crisis situation to justify regulatory support. In this regard we add to existing literature on how crisis inspires political change, to show how real estate actors position themselves as essential to understanding what this change should be.

Third, we use the London case to show that whilst crises are endemic to market and political systems (Jessop, 2002), what is of significance is how they are understood and used to justify subsequent forms of practice, management, and regulation. In our case work, we show that responses are driven and informed by those actors able to re-orientate themselves, relative to policymakers, in response to the crisis and legitimate their activities as essential to the alleviation of a crisis situation. More broadly, this demonstrates further what naming the situation a crisis does, encouraging us to think about how in naming the catastrophe of the housing affordability provision and failure of the London system as a 'crisis' has facilitated its further entrenchment of volume housebuilders and large advisory firms, and how re-casting it in another way might enable a push-back against the current ways of understanding the housing system within the real estate profession.

And finally, the work also sheds light on how the imposition of market-driven systems of regulatory reform that seek to mobilise private sector resources and capacities directly into the delivery of public policy integrate the spheres of the political and markets in more direct and recursive ways. Market failures within the housing sector become fundamental problems for politicians and regulators, who are faced with crises of legitimation and governability. However, as market actors take a direct role in housing provision of all types, including social and affordable housing, they become subject to greater political scrutiny and face new regulatory risks and these, in turn, impact on their market practices. In the case of London, we have shown that their strategies to negotiate such risks, lead them towards market interventions and innovations that perpetuate and displace the housing crisis, and will consistently be unable solve it. Moreover, outside of big urban centres, where property markets are flat or even in decline, the character of the housing 'crisis' is even more detached from market-centred narratives and less likely to be tackled by entrepreneurial policy reforms. To tackle problems in a more structural way thus requires a re-focusing of public policy away from supply-side descriptions and prescriptions towards a more rounded view of housing as both a market and non-market product that is governable and around which collective modes of allocation and legitimation are negotiated. Rather than encouraging more investment in the supply of housing in fast growing places, a very different set of 
agendas is required that could redistribute demographic and economic growth in a coordinated and more spatially just manner. Such an approach would, in the longer term, re-calibrate discussions over who and what housing is for.

\section{Declaration of competing interest}

None.

\section{Acknowledgements}

The authors would like to thank the WHIG team for their support in developing these ideas, and the three reviewers for their productive and generous comments. The research was supported by ESRC grant ES/ S015078/1.

\section{References}

Adisson, F., \& Artioli, F. (2019). Four types of urban austerity: Public land privatisations in French and Italian cities. Urban Studies, 57(1), 75-92.

Amirtahmasebi, R., Orloff, M., Wahba, S., \& Altman, A. (2016). Regenerating urban land: A practitioners guide to leveraging private investment. Washington, DC: World Bank. htt ps://doi.org/10.1596/978-1-4648-0473-1.

Atkinson, R. (2019). Necrotecture: Lifeless dwellings and London's super-rich. International Journal of Urban and Regional Research, 43(1), 2-13. https://doi.org/ 10.1111/1468-2427.12707

Barratt Developments. (2017). Building excellence. https://www.barrattdevelopments.co. uk/ /media/Files/B/Barratt-Developments/reports-presentation/2017/barratt-ar 17.pdf.

Baum, A., \& Hartzell, D. (2011). Global property investment: Strategies, structures, decisions. Global property investment: Strategies, structures. Decision. https://doi. org/10.1002/9781444347289

Beswick, J., Alexandri, G., Byrne, M., Vives-Miró, S., Fields, D., Hodkinson, S., \& Janoschka, M. (2016). Speculating on London's housing future. City, 20(2), 321-341. https://doi.org/10.1080/13604813.2016.1145946

Brill, F., \& Durrant, D. (2021). The emergence of a Build to Rent model: The role of narratives and discourses. Environment and Planning A: Economy and Space. https:// doi.org/10.1177/0308518X20969417

Brill, F. N., \& Robin, E. (2019). The risky business of real estate developers: Network building and risk mitigation in London and Johannesburg. Urban Geography, 1-19. https://doi.org/10.1080/02723638.2019.1637211

Cheshire, P. (2019). Paul cheshire on urban economics. https://unassumingeconomist. com/2019/03/paul-cheshire-on-urban-economics/. (Accessed 11 May 2021).

Colenutt, B. (2020). The property lobby: The hidden reality behind the housing crisis. Bristol: Bristol University Press. https://doi.org/10.2307/j.ctvzsmcrm

Crouch, C. (2013). The strange non-death of neo-liberalism. John Wiley \& Sons.

DCLG. (2017). Fixing_our_broken_housing_market_-_print_ready_version.pdf. (n.d.). Retrieved from https://assets.publishing.service.gov.uk/government/uploads/sy stem/uploads/attachment_data/file/590464/Fixing_our_broken_housing_market _-_print_ready_version.pdf.

De Magalhaes, C., Freire Trigo, S., Gallent, N., Scanlon, K., \& Whitehead, C. (2018). PLANNING RISK AND DEVELOPMENT How greater planning certainty would affect residential development, Article 04968. https://doi.org/10.13140/RG.2.2.19009

Dorling, D. (2014). All that is solid: How the great housing disaster defines our times, and what we can do about it. Penguin UK.

Edwards, M. (2016). The housing crisis and London. City, 20(2), 222-237. https://doi. org/10.1080/13604813.2016.1145947

Ferm, J., \& Raco, M. (2020). Viability planning, value capture and the geographies of market-led planning reform in england. Planning Theory \& Practice. https://doi.org/ 10.1080/14649357.2020.1754446

Gallent, N., Durrant, D., \& May, N. (2017). Housing supply, investment demand and money creation: A comment on the drivers of London's housing crisis. Urban Studies, 54(10), 2204-2216. https://doi.org/10.1177/0042098017705828

Halbert, L., \& Rouanet, H. (2014). Filtering risk away: Global finance capital, transcalar territorial networks and the (Un)Making of city-regions: An analysis of business property development in Bangalore, India. Regional Studies, 48(3), 471-484. https:// doi.org/10.1080/00343404.2013.779658
Henneberry, J., \& Parris, S. (2013). The embedded developer: Using project ecologies to analyse local property development networks. Town Planning Review, 84, 227-249. https://doi.org/10.2307/23474329

Heslop, J., \& Ormerod, E. (2020). The politics of crisis: Deconstructing the dominant narratives of the housing crisis. Antipode, 52, 145-163. https://doi.org/10.1111/ anti.12585

Holgersen, S. (2014). Urban responses to the economic crisis: Confirmation of urban policies as crisis management in malmö. International Journal of Urban and Regional Research, 38(1), 285-301. https://doi.org/10.1111/1468-2427.12029

Immergluck, D. (2011). The local wreckage of global capital: The subprime crisis, federal policy and high-foreclosure neighborhoods in the US. International Journal of Urban and Regional Research, 35, 130-146. https://doi.org/10.1111/j.14682427.2010.00991.x

Jessop, B. (2002). Bringing the state back in (yet again): Reviews, revisions, rejections, and redirections. International Review of Sociology, 11(2), 149-173. https://doi.org/ $10.1080 / 713674035$

JLL. (2014). The supply conundrum. Retrieved September 4 2019: http://residential.jll. co.uk/insights/research/residential-forecast-report-the-supply-conundrum-novembe r-2014.

JLL. (2017a). Central London development report. Retrieved 4 September 2019 htt p://residential.jll.co.uk/insights/research/central-london-development-report-sept2017.

JLL. (2017b). South east London. Retrieved September 4 2019: http://residential.jll.co. uk/insights/research/south-east-london.

JLL. (2017d). A problem shared. Retrieved September 4 2019: http://residential.jll.co. uk/insights/research/shared-ownership-time-is-now-January-2017.

JLL. (2018a). Micro-living report. Retrieved 4 September 2019 http://residential.jll.co. uk/insights/news/micro-living-report-july-2018.

JLL. (2018b). Micro solutions to a macro problem. Retrieved September 4 2019:http://re sidential.jll.co.uk/insights/research/micro-solutions-june-2018 .

Kichanova, V. (2016). Size doesn't matter: Giving a green light to micro-homes. Adam Smith Institute. https://static1.squarespace.com/static/56eddde762cd9413e151ac92/t/5c 41d02f0ebbe8aa256c361c/1547817061183/Size+Doesn\%27t+Matter+-+Vera+ Kichanova.pdf.

Klein, N. (2014). The shock doctrine: The rise of disaster capitalism. Penguin UK.

Madden, D. J., \& Marcuse, P. (2016). In defense of housing: The politics of crisis. Verso.

O'Callaghan, C., Boyle, M., \& Kitchin, R. (2014). Post-politics, crisis, and Ireland's 'ghost estates'. Political Geography, 42, 121-133. https://doi.org/10.1016/j. polgeo.2014.07.006

Özogul, S., \& Tasan-Kok, T. (2020). One and the same? A systematic literature review of residential property investor types. Journal of Planning Literature, 35(4), 475-494. https://doi.org/10.1177/0885412220944919

Penny, J. (2019). 'Defend the Ten': Everyday dissensus against the slow spoiling of Lambeth's libraries. Environment and Planning D: Society and Space. https://doi.org/10.1177/ 0263775819893685

Raco, M., Livingstone, N., \& Durrant, D. (2019). Seeing like an investor: Urban development planning, financialisation, and investors' perceptions of London as an investment space. European Planning Studies, 27(6), 1064-1082. https://doi.org/ 10.1080/09654313.2019.1598019

Riles, A. (2018). Financial citizenship: Experts, publics, and the politics of central banking. Cornell University Press.

Robin, E. (2018). Performing real estate value(s): Real estate developers, systems of expertise and the production of space. Geoforum. https://doi.org/10.1016/j. geoforum.2018.05.006

Robinson, J., \& Attuyer, K. (2021). Extracting value, London style: Revisiting the role of the state in urban development. International Journal of Urban and Regional Research, 45, 303-331. https://doi.org/10.1111/1468-2427.12962

Roitman, J. (2013). Anti-crisis. Duke University Press.

Rolnik, R. (2019). Urban Warfare: Housing under the Empire of Finance. Verso Books.

Ryan-Collins, J., Lloyd, T., \& Macfarlane, L. (2017). Rethinking the economics of land and housing. Zed Books Ltd.

Shelter. (2019). Building for our future: A vision for social housing. London: Shelter.

Wacquant, L. (2012). Three steps to a historical anthropology of actually existing neoliberalism. Social Anthropology, 20(1), 66-79.

Walby, S. (2015). Crisis. Cambridge: Polity Press, ISBN 978-0-7456-4760-9.

Watt, P., \& Minton, A. (2016). London's housing crisis and its activisms. City, 20(2), 204-221. https://doi.org/10.1080/13604813.2016.1151707

Williams, C. (2020). 'Special report - housing'. The Economist. January 18.

Žižek, S. (2014). Absolute recoil: Towards a new foundation of dialectical materialism. Verso Books.

Žižek, S. (2017). The courage of hopelessness: Chronicles of a year of acting dangerously. Allen Lane, an imprint of Penguin Books. 